\title{
A popularização da fotografia e seus efeitos: Um estudo sobre o a disseminação da fotografia na sociedade contemporânea e suas consequências para os fotógrafos e suas produções
}

\author{
The popularization of photography and its effects: \\ A study on the the spread of photography in contemporary society and its \\ consequences for photographers and their productions
}

\author{
Kawakami ,Tatiana Tissa; Graduanda; \\ Universidade Norte do Paraná - UEL \\ tissattk@gmail.com
}

\author{
Veiga, Adriana Imbriani Marchi; Mestre; \\ Universidade Estadual de Londrina - UEL \\ adrimarchiveiga@hotmail.com
}

\section{RESUMO}

O presente artigo traz discussões acerca da fotografia como forma de linguagem. Esta tem sido largamente utilizada como meio de comunicação visual de grande apelo popular, é bastante conhecida e, relativamente, de fácil acesso na sociedade contemporânea. Em decorrência do desenvolvimento tecnológico, as câmaras digitais fotográficas e os processos de produção de fotografias tornaram-se cada vez mais dinâmicos e, de certa forma, facilitados. Tal facilidade contribuiu imensamente para a disseminação da fotografia como meio de comunicação visual. Com base em referenciais teóricos que versam sobre a fotografia e em uma pesquisa de campo, que abrangeu leigos e profissionais da área da fotografia, desenvolveu-se discussões acerca da popularização da imagem na sociedade contemporânea, e, conseqüentemente, sobre o papel do fotógrafo neste contexto, com o objetivo de se analisar e refletir sobre o papel do produtor e sua produção fotográfica neste cenário de constantes transformações.

Palavras Chaves: fotografia, fotógrafo, evolução tecnológica, linguagem visual.

\section{ABSTRACT}

This article discusses about photography as a form of language. Photography is used as a way to communicate visually due to its popularity and, relatively easy access to the contemporary society. Because of the evolution of technology, the photographic cameras and processes that generate photography are becoming increasingly dynamic and facilitated. This facility contributes to the dissemination of photography as a way of visual communication. Based on theoretical references about photography and field research with laymen and professional photographers, it was developed a discussion over the image's popularization and the purpose of the photographers and their productions in this context. It is in this context of constant changes that it is raised the discussion about the value of photography and photographers on the contemporary society.

Keyword: Photography, photographer, evolution of technology, visual language.

\section{Introdução}

O desenvolvimento das mídias e a acelerada modernização dos processos de produção da 
A popularização da fotografia e seus efeitos: ... e suas consequências para osfotógrafos e suas produções

imagem tornam cada vez mais abundante o acervo de informações visuais presentes no cotidiano, porém, a sociedade mostra-se pouco apta para acompanhar tais avanços.

Essa enorme produção de informações visuais exige do receptor um grau de percepção e absorção cada vez mais apurado, entretanto, o que se encontra é um público receptor, por vezes, desavisado quanto ao potencial da linguagem visual, e que, por este motivo, não a trata com a devida atenção.

A fotografia é um dos meios de comunicação visual que alcança boa parcela da sociedade e que possui uma grande credibilidade junto à mesma, devido ao seu contexto histórico social. Em decorrência do forte desenvolvimento tecnológico alcançado pelas indústrias, a máquina fotográfica tornou-se um bem de consumo de relativa acessibilidade à população. Com custos reduzidos e com uma forma cada vez mais compacta, a câmera fotográfica é um objeto presente no cotidiano da sociedade, tendo deixado, há tempos, de ser item exclusivo de profissionais da área.

Se fotografias estão sendo produzidas a todo momento, por pessoas de diferentes áreas de atuação, o que define, atualmente, um fotógrafo profissional? Quais os efeitos trazidos pela popularização da imagem fotográfica aos profissionais da área e suas produções? Qual a visão da sociedade sobre tal popularização? É em torno dessas questões que se desenvolveu a discussão do presente artigo, que objetiva produzir reflexões acerca da evolução da fotografia e seus efeitos.

Tem-se por objetivo com este estudo Refletir sobre os efeitos da democratização/popularização da fotografia sobre os fotógrafos e para a sociedade como um todo; Analisar as consequências que a democratização/popularização da fotografia trouxe em relação à qualidade técnica e à estética da imagem fotográfica; Verificar o quanto o avanço tecnológico contribuiu para as transformações na vida profissional do fotógrafo e, consequentemente, para a sua produção;

Para alcançar os objetivos propostos foi necessário traçar um levantamento bibliográfico sobre o tema, assim como, realizar uma pesquisa de campo por meio da aplicação de dois questionários.

Foi realizado um levantamento bibliográfico objetivando relacionar os principais autores que contribuíram para o desenvolvimento da pesquisa na abordagem sobre os efeitos da democratização/ popularização da fotografia sobre os fotógrafos; as consequências que a democratização/popularização da fotografia trouxe para a qualidade técnica e estética da imagem fotográfica; e o quanto o avanço tecnológico contribuiu para as transformações na vida profissional do fotógrafo e, consequentemente, para a sua produção. Esse embasamento teórico foi desenvolvido de forma a explanar a evolução da fotografia e assuntos correlatos.

Para complementar o levantamento bibliográfico, foram realizadas pesquisas de campo, sendo utilizados dois questionários como instrumentos de pesquisa.

O primeiro questionário, de ordem qualitativa, é constituído por perguntas subjetivas e tem como público alvo aqueles que vivem da fotografia, conhecidos como fotógrafos profissionais. 0 segundo questionário é objetivo e busca atingir a sociedade como um todo, sem restrições de nível social ou acadêmico.

Os profissionais entrevistados correspondem às mais variadas áreas da fotografia, abrangendo os gêneros artístico, fotojornalismo, documental, social, ambiental e comercial. As questões presentes nesse instrumento de pesquisa objetivaram analisar a opinião dos profissionais da área quanto às mudanças trazidas ao campo profissional em decorrência do avanço tecnológico. Buscou-se, também, compreender como os entrevistados encaram a crescente popularização do equipamento fotográfico e, consequentemente, da própria fotografia. Além disso, procurou-se analisar como é encarada pelos fotógrafos a disseminação da imagem fotográfica na sociedade contemporânea. 0 questionário foi encaminhado para 30 profissionais da área e obteve-se resposta de 15 deles. Nas citações das entrevistas, para que a privacidade dos entrevistados fosse mantida, os entrevistados foram enumerados, aleatoriamente, de 1 a 15.

Quanto ao questionário de múltipla escolha, de ordem quantitativa, o mesmo é voltado ao público geral (sem restrição de faixa etária, gênero, classe social ou escolaridade), esse foi desenvolvido de forma a buscar compreender a maneira como é vista a fotografia pela sociedade como um todo. Procurou-se, também, entender a função do fotógrafo de acordo com a opinião da sociedade, além de se investigar o grau de acessibilidade da fotografia no cenário contemporâneo. Para isso, foram 
entrevistadas 100 pessoas.

\section{Sobre a forma como é tratada a linguagem visual}

Parte da humanidade tem demonstrado, ao longo da história, certa preferência pela comunicação verbal, sendo esta relacionada, diretamente, à orientação de informações e ensino. Essa supervalorização da linguagem verbal em detrimento da linguagem visual é, no mínimo, curiosa, como afirma Moreiro (2003), pois a imagem se faz presente e é fundamental ao meio cultural, científico (no que se diz respeito aos processos educacionais e modos de produção) e pessoal.

A linguagem visual apresenta crescente significância enquanto meio de expressão na sociedade contemporânea, e estando tão presente, presume-se que o estudo da mesma seja de grande relevância.

Com o desenvolvimento de mídias e a acelerada modernização dos processos de produção da imagem, torna-se cada vez mais abundante o acervo de informações visuais presentes no cotidiano da sociedade, porém, a sociedade tem se mostrado pouco apta a acompanhar tais avanços.

A produção desenfreada de informações visuais exige do receptor um grau de percepção e absorção cada vez mais apurado. Porém, o que se observa são receptores despreparados e, por vezes, alienados quanto ao poder da linguagem visual, que não tratam as imagens com a devida atenção, deixando de analisá-las aprofundadamente, ao permanecerem na superficialidade de informações "pré-digeridas".

É curioso observar a falta de atenção com que, muitas vezes, as informações visuais são tratadas no mundo contemporâneo, uma vez que as imagens nunca se fizeram tão presentes e imperativas.

Quanto à onipresença da linguagem visual, Abbott (1980 apud FABRIS, [ca. 2007], p. 1) observa que:

O mundo hoje está condicionado, irresistivelmente, a visualizar. A imagem quase substituiu a palavra como meio de comunicação. Tablóides, filmes educativos e documentais, películas de massa, revistas e televisão rodeiam-nos.

Assim como a linguagem verbal, a linguagem visual é riquíssima e igualmente permeada por obstáculos, porém, esta última tem sido tratada com certo descaso. Como afirma Donis (2007), a linguagem visual acaba, por vezes, sendo submetida apenas a critérios de análise, frequentemente, questionáveis, determinados pelo gosto pessoal.

Sobre a forma como é encarada a linguagem visual, Donis coloca que,

Uma das tragédias do avassalador potencial do alfabetismo visual em todos os níveis da educação é a função irracional, de depósitaria da recreação, que as artes visuais desempenham nos currículos escolares, e a situação parecida que se verifica no uso dos meios de comunicação, câmeras, cinema, televisão. Por que herdamos, nas artes visuais, uma devoção tácita ao não-intelectualismo? [...] (DONIS, 2007, p.17)

O poder informativo latente nas imagens, por vezes, é desperdiçado em decorrência do desconhecimento por parte dos leitores visuais. É comum a rotulação, mesmo que inconsciente, dos meios de comunicação visual: as pinturas são consideradas "obras de arte" a serem admiradas, o cinema é diretamente relacionado às produções comerciais de Hollywood, e a fotografia incumbe-se das tarefas de documentação e registro. Essa categorização de "funções" é, no mínimo, questionável.

Ao se encarar um meio de comunicação visual como passível de apenas um nível de leitura, seja ela documental, sociológica, poética, entre outras, inevitavelmente, acaba-se por empobrecer sua interpretação e subestimar as informações ali presentes.

\section{Fotografia como linguagem visual}

A fotografia pode ser encarada como uma forma de linguagem visual, pois "é uma manifestação 
imagética e, portanto, capaz de gerar múltiplas leituras; conseqüentemente, múltiplos sentidos [...]" (CAMARGO; COSTA in BONI, 2008, p. 83). Portanto, atribui-se à fotografia o potencial da comunicação e desenvolvimento de discurso, mesmo que em um nível diferente da linguagem verbal.

A imagem fotográfica foi, desde que surgiu, o ponto para onde convergiram múltiplos discursos: discurso técnico, estético, literário, filosófico, psicanalítico, semiótico, sociológico e antropológico, discursos sobre seus estilos, seus gêneros, seus possíveis usos; discursos daqueles que a faziam e debates que essa imagem suscitava nos meios artísticos. (SAMAIN, 2005, p. 14)

A linguagem fotográfica, como foi citado anteriormente, é capaz de comportar os mais variados discursos, no entanto, a mesma tem sido encarada, em muitos momentos da história e por grande parte da sociedade, como depositária apenas da função de registro ou documento. Tal fato é, no mínimo incomodo, pois a fotografia tem capacidade para transmitir muito mais do que o senso comum lhe atribui. Certamente, a rotulação da imagem fotográfica como forma de registro fidedigno da realidade deve-se a uma série de fatores, no entanto, esse é um assunto que será discutido posteriormente.

Assim como o texto, a fotografia também é passível de leitura. Apesar desta não ter a mesma ênfase que a linguagem verbal nas grades acadêmicas, a interpretação de "textos visuais" mostra-se largamente presente no cotidiano da sociedade. A interpretação da linguagem fotográfica está presente mesmo quando não notamos, pois ela é feita quase que automaticamente, afinal "quando vemos uma imagem fotográfica e lhe atribuímos um sentido estamos lendo aquela imagem." (CAMARGO, 1999, p.149).

Benjamin $(1985$, p.107) reforça a ideia da fotografia como forma de linguagem ao colocar que já "se disse que o "analfabeto do futuro não será quem não sabe escrever, e sim quem não sabe fotografar". Mas um fotógrafo que não sabe ler suas próprias imagens não é pior que um analfabeto?".

O questionamento levantado por Benjamin (1985), apesar de ter sido feito há algumas décadas, mostra-se bastante relevante no cenário contemporâneo, principalmente porque, anteriormente, dificilmente se fizeram tão presentes as imagens fotográficas e a facilidade com que elas são produzidas por, praticamente, qualquer indivíduo. Dessa forma, levanta-se o questionamento acerca da real compreensão que se tem sobre a fotografia.

\section{Sobre a fotografia}

"Toda máquina começa pela imitação de uma capacidade humana que ela se torna, então, capaz de amplificar [...]" (SANTAELLA in org.DOMINGUES, 1997, p.35). Com a máquina fotográfica não foi diferente, pois esta, nada mais é que uma simulação do funcionamento do próprio aparelho óptico humano.

De acordo com Samain (2005), a matéria-prima da fotografia é a própria luz, pois a sua incidência sobre as mais diversas superfícies é refratada ou refletida, produzindo assim a imagem. 0 fotógrafo, apesar de seus artifícios e esforços, não consegue manipular a luz com a mesma facilidade com que o pintor maneja as tintas, sendo assim, torna-se compreensível a tendência de interpretar a fotografia como uma imagem que se prende ao registro, limitando-se a um reflexo do real.

Essa ligação entre a fotografia e a especularização do mundo em que vivemos é explicada por Machado (1984), que considera que o advento da fotografia não pode ser confundido com o desvendar das placas sensíveis à luz, pois, antes disso, contextualizada no Renascimento, proliferou-se a câmera fotográfica em sua face mais "primária", a câmera escura. Tal aparelho era utilizado frequentemente por pintores renascentistas como um meio para alcançar produções mais "realistas".

Sendo assim, a gênese da fotografia tem como fundamento a satisfação de uma necessidade humana, ou seja, a especularização da realidade.

A capacidade de representar o mundo real de maneira (aparentemente) fidedigna é o que torna a fotografia tão poderosa. Camargo (1999) observa que 
"As fotografias têm o poder da presentação, tornar presente algo ausente [...] este poder que faz da fotografia um referente tão forte e tão eficaz que nos faz dispensar as traduções ou interpretações, medidas por outras linguagens, que não a da própria fotografia. A fotografia é autosignificante." (CAMARGO, 1999, p.195)

Ao longo do desenvolvimento da fotografia pode-se observar grandes mudanças no modo pelo qual a mesma foi tratada.

\section{Sobre a fotografia contemporânea}

Em decorrência do forte desenvolvimento tecnológico, a máquina fotográfica vem se tornando um bem de consumo de relativa acessibilidade à população. Com custos reduzidos e cada vez mais compacta, a câmera fotográfica é um objeto presente no cotidiano da sociedade, tendo deixado, há tempos, de ser item exclusivo de profissionais da área.

Segundo Camargo (1999), a relativa facilidade com que são produzidas as fotografias, no que se refere à "rapidez" com que elas podem ser "geradas" (traçando-se um paralelo com a produção de uma pintura, por exemplo), fez com que fosse incutido na sociedade o preceito de que, para fotografar, não é necessário haver qualquer tipo de habilidade artística ou conhecimento estético. Tal preceito foi fator fundamental na disseminação da fotografia, porém, trouxe também certos efeitos negativos.

A fabricação desenfreada de fotografias, ao produzir um contingente gigantesco de informações, acabou por "saturar" o leitor visual, levando-o, não raro, a optar, em suas leituras, por informações mais primárias e menos analíticas.

Sendo assim, de certa forma, pode-se dizer que a produção exacerbada de fotografias fez com que a mesma acabasse por ser banalizada. Pode parecer extremo, no entanto, para muitos, as fotografias são vistas como veículos visuais que podem ser produzidos por qualquer um que saiba disparar o botão da máquina fotográfica.

No que se refere à presença de imagens fotográficas na sociedade, Barthes afirma:

Vejo fotos por toda parte, como todo mundo hoje em dia; elas vêm do mundo para mim, sem que eu peça; não passam de "imagens", seu modo de aparição é o tudoo-que-vier (ou tudo-o-que-for) [...]. (BARTHES, 1984, p. 31)

Ainda sobre a forte presença da fotografia no cotidiano da sociedade, Flusser ressalta que:

Fotografias são onipresentes: coladas em álbuns, reproduzidas em jornais, expostas em vitrines, paredes de escritórios, afixadas contra muros sob formas de cartazes, impressas em livros, latas de conservas, camisetas. Que significam tais fotografias? (FLUSSER, 1985, p.22)

Apesar de ter sido levantada, há tempos, por Flusser (1985), a questão em torno do significado das fotografias que nos cercam mostra-se extremamente compatível com o cenário contemporâneo. Dificilmente, um indivíduo inserido no contexto urbano conseguirá passar um dia sem deparar-se, ao menos, com uma fotografia. Essas imagens fotográficas, tão presentes na vida da sociedade, normalmente são tidas como forma de registro/documentação de fatos ou cenas. Ao se falar em fotografia, imediatamente, vêm à mente imagens empregadas em jornais, revistas ou álbuns de família. Raramente ela é vista sob outras interpretações, porém, atualmente, sabe-se que existem também fotógrafos que fazem de seus trabalhos uma forma de arte, um exemplo disso é a crescente presença de exposições de fotografias em bienais.

Referindo-se ao papel de expressão individual que pode ser assumido pela fotografia, Kossoy afirma que:

A fotografia pode ser um meio de expressão individual, sempre se prestou a incursões puramente estéticas; a imaginação criadora é pois inerente a essa 
forma de expressão; não pode ser entendida apenas como registro da realidade dita factual. A deformação intencional dos assuntos através das possibilidades de efeitos ópticos e químicos, assim como a abstração, montagem e algeração visual da ordem natural das coisas, a criação enfim de novas realidades tem sido exploradas constantemente por fotógrafos. (KOSSOY, 2003, p.49)

Com o advento da fotografia, houve grandes mudanças em relação ao modo como são, hoje, tratadas as artes, como foi observado por Moreiro (2003), pois a fotografia "tomou" a função das pinturas de registro do real. Os artistas tiveram como primeira reação tentar "competir" com a fotografia, no entanto, com o passar do tempo, a fotografia passou a ser encarada não mais como um concorrente, e sim como um instrumento do qual os artistas podiam se utilizar para produzir arte. Em suma, anteriormente à fotografia, deu-se o advento da pintura e, posteriormente, o advento do vídeo, do cinema e dos televisores.

A discussão em torno da possibilidade de a fotografia tornar-se ultrapassada é largamente explorada por estudiosos. Alguns autores afirmam que a fotografia está se tornando obsoleta, como pondera Machado:

Já é um lugar-comum dizer que entramos no universo das imagens pós-fotográficas. A cada novo dia, multiplicam-se em progressão geométrica as telas de vídeo ao nosso redor [...] Novas paisagens começam a acumular-se, novas escrituras se insinuam, outros códigos de representação nos tomam de salto. (MACHADO in DOMINGUES, 2001, p.45)

No entanto, há aqueles que se opõem a esse conceito de "processo de extinção" da fotografia, defendendo a idéia de que "Basta você ver quanto ela é utilizada e das mais variadas maneiras. Ela é uma linguagem que está longe de ter chegado à exaustão." (BENEDICTO in PERSCHIETTI, 2000, p. 60).

Porém, mais do que a possibilidade do desuso da fotografia, discute-se o domínio da fotografia digital em detrimento da analógica. Há, na atualidade, certo domínio da fotografia digital, pois se pode dizer que seu custo de produção é mais baixo em relação ao da imagem originada em equipamentos analógicos, sem mencionar a inegável rapidez com que ela é produzida. No entanto deve-se notar a "sobrevivência" da imagem analógica, Martinelli observa que não se pode "achar que a fotografia digital vai derrubar a tradicional. Você não pode dizer: a partir de agora acabaram os filmes, acabou o papel. [...] Uma coisa ajuda a outra [...]" (in PERSICHIETTI, 2000, p.48).

É natural o advento de novos meios de comunicação visual, pois a própria sociedade, o próprio ser humano e sua forma de pensar se modificam, "assim sendo, a função que uma imagem cumpria na pré-história não é a mesma que cumpre na sociedade contemporânea." (CAMARGO; COSTA in BONI, 2008 , p. 84), logo, as fotos geradas por processos analógicos assumirão um novo papel, porém, não deixarão de ter o seu valor e continuarão sendo produzidas, mesmo que em menor escala.

Juntamente com o avanço tecnológico e com o desenvolvimento de novos e modernizados aparelhos fotográficos, foram evoluindo, também, as formas como são dispostas as imagens produzidas por tais equipamentos.

Com o avanço da tecnologia, os processos digitais tornam-se cada vez mais significativos no contexto da comunicação. A internet impera como veículo de transmissão de informações por sua onipresença, pois uma pessoa, no Brasil, pode ter acesso às mesmas informações no mesmo instante em que as tem uma pessoa na China ou em qualquer outra parte do mundo. Isso dificilmente aconteceria com tamanha facilidade antes do advento da internet. Essa agilidade e dinamismo trazidos pela internet conferiram grandes mudanças ao cenário da fotografia, pois, da mesma forma que notícias e e-mails são trocados, quase que instantaneamente, as fotografias também passaram a dispor dessa rapidez.

Ao desenvolver esses modernos aparatos tecnológicos, talvez o homem não tenha se dado conta das mudanças que seriam trazidas em decorrência de tais inventos. Nesse sentido, Fróes ressalta que:

[...] da mesma forma como a criatividade inventiva do homem gera novas ferramentas 
tecnológicas, e modifica constantemente os instrumentos que inventa, existe um efeito inverso: a tecnologia modifica a expressão criativa do homem [...]. (FRÓES, 2008, p. 2)

O pensamento de Fróes traduz, de maneira surpreendentemente objetiva, o que ocorreu com a fotografia nas últimas décadas. A invenção de novos equipamentos e recursos que, de certa forma, facilitaram o processo de produção e disseminação das fotografias, produziu uma série de "efeitos colaterais".

Anteriormente, os fotógrafos dependiam quase que exclusivamente de aprovações em galerias para que pudessem exibir suas imagens, porém, atualmente, embora ainda seja necessário submeterse a tal crivo, existem também outras opções. Em decorrência do advento da internet, tornou-se muito mais fácil a exposição de fotografias por meio de fotologs, blogs, sites de bancos de imagens (como o flickr) etc. Qualquer um pode expor suas fotografias por meio da internet, independente da qualidade técnica, da conceituação ou do assunto nelas abordado, e isso conferiu ao produtor das imagens maior liberdade.

\section{Sobre o fotógrafo}

Para que haja fotografia, é necessário que haja o fotógrafo, afinal, "as imagens não falam por si só, nós é que nos falamos através delas [...]" (CAMARGO, 1999, p.110).

Para se entender quais os papéis desempenhados pela fotografia na sociedade, é necessário compreender, também, o papel e a importância do autor de tais imagens, ou seja, o fotógrafo, pois "a fotografia incorpora a assinatura do fotógrafo que retrata o que acredita ser importante, seja pela beleza, seja pelo significado atribuído a cena" (PACOLA; LAHAN in BONI, 2008, p.182).

Ao procurar pelo termo fotógrafo em dicionários, não raro, encontra-se somente a definição da palavra fotografia ou do verbo fotografar. Exemplo disso é a forma como é tratado tal assunto por Ferreira (2008, p. 416): "fo.to.gra.fia sf. 1. Processo de registrar imagens mediante a ação da luz sobre o filme (1) 2. imagem assim obtida; foto. § fo.to.gra.fi.co adj; fo.tó.gra.fo sm." Mas essa definição pode ser um tanto quanto vaga e evasiva, pois não se aprofunda em conhecimentos acerca do assunto.

Muito se discursa e estuda acerca da fotografia, de suas origens, do processo evolutivo por que passou e suas funções, porém, como já foi afirmado, faz-se igualmente necessário compreender o autor de tais imagens, o fotógrafo. É interessante observar que, em seus estudos, Barthes (1984) trata do fotógrafo por meio do termo "Operador". Tal denominação pode parecer reduzir o fotógrafo a um mero operante do aparelho fotográfico, bastando apenas que este tenha conhecimentos técnicos em torno do assunto. No entanto, o termo "Operador" revela-se com um significado completamente diferente, pois, ao tecer estudos acerca da "Fotografia-segundo-o-fotógrafo", o autor o interpretou como o responsável pela essência da fotografia, sendo assim, este deixa de ser reduzido a um indivíduo cujas mãos são responsáveis apenas pelo disparador da câmera fotográfica.

O que define, então, um fotógrafo, além de suas habilidades técnicas? É muito comum a expressão "fotógrafo amador" e "fotógrafo profissional", mas o que significam, realmente, tais termos? Kossoy (2003) traz certo esclarecimento sobre esse assunto ao observar que há fotógrafos que produzem fotografias atemporais, que serão tidas como significativas e importantes, independentemente da época em que são analisadas, e há fotógrafos que produzem, simplesmente, uma imagem sem maiores valores.

A partir disso, é possível analisar o quanto a sensibilidade, o poder criativo e a experiência cultural do autor da foto influenciam no resultado atingido.

Camargo (1999) faz uma análise interessante, ao levantar a questão de que, como qualquer outro instrumento tecnológico, a câmera fotográfica opera de acordo com certos limites e determinações definidas por seus fabricantes, e tais limitações são interpretadas/tratadas de diferentes formas, de acordo com cada fotógrafo. $O$ autor coloca ainda que,

Para o fotógrafo incidental, estes limites soam como orientação para a busca da foto ideal: focada, iluminada e congelada. Mas para aqueles que operam no do campo 
A popularização da fotografia e seus efeitos: ... e suas consequências para osfotógrafos e suas produções

das imagens expressivas ou experimentais, o trabalho é justamente o de readequar as imposições dos aparelhos, subverter a prescrição técnica oriunda das câmeras, de seus ajustes (subverter o software) e dos materiais de tal modo que a expressão e a identidade fluam libertas e constituam em estilos. (CAMARGO, 1999, p. 222)

O envolvimento do fotógrafo com o assunto fotografado é de grande relevância, pois, "se fotografar é conferir importância a algo que atrai nosso interesse, então o respeito pelo que fotografamos é compreensível e indispensável" (FELIZARDO in PERSCHIETTI, 2000, p.144), sendo assim, além de fotógrafo, deve-se ser, também, um eterno estudioso acerca dos assuntos abordados nas produções fotográficas. Pode-se, então, cogitar que uma das diferenças entre o amador e o profissional reside em seu grau de consciência sobre o seu próprio trabalho.

O que difere um do outro, de qualquer forma, não exclui nenhuma das partes, seja amador ou profissional, o fotógrafo deve

[...] testemunhar, assistir, enxergar, divisar, distinguir, perceber, percorrer, encontrar, observar, deduzir, construir, imaginar, fantasiar, examinar, investigar, calcular, prever, ponderar, considerar, julgar, reconhecer, contemplar, mirar... (FIRMO in PERSCHIETTI, 2000, p.106).

\section{Resultados e Discussões}

A fotografia possui um longo histórico, pois a câmara obscura foi evoluindo até chegar aos hoje tão comuns, aparatos tecnológicos digitais. Concomitante à evolução do equipamento fotográfico, houve um desenvolvimento e uma modificação do próprio fotógrafo e de suas produções.

Para se investigar o cenário evolutivo da fotografia contemporânea, foram utilizados, como instrumento de pesquisa, dois questionários, um (quantitativo) direcionado à sociedade geral, e outro (qualitativo), direcionado apenas aos fotógrafos profissionais. A utilização desses dois instrumentos de pesquisa objetivou evitar obter-se uma visão unilateral, seja apenas por parte de leigos, ou apenas por profissionais. Buscou-se entrelaçar os resultados dos dois questionários no desenvolvimento da presente discussão.

O questionário subjetivo foi encaminhado, via e-mail, para 30 profissionais da área, obtendose resposta de 15 pessoas, todos atuantes no mercado de trabalho como fotógrafos profissionais nas áreas social, comercial, artística, ambiental e jornalística. Os respondentes residem nas cidades de Londrina, Rio de Janeiro, São Paulo e Salvador. Buscou-se entrevistar fotógrafos que produziram/ produzem tanto no formato analógico quanto digital, já que o presente estudo objetiva, sobretudo, analisar os efeitos da evolução tecnológica junto aos fotógrafos e às suas produções. 0 tempo de profissão dos entrevistados varia de 6 a 40 anos de experiência, sendo a média de 19 anos de atuação. Nas citações das entrevistas, para que a privacidade dos entrevistados fosse mantida, os entrevistados foram enumerados aleatoriamente de 1 a 15.

Já o questionário de múltipla escolha abrangeu, aleatoriamente, a população, não havendo restrições de idade, gênero ou grau de escolaridade. O questionário foi distribuído de duas formas, via e-mail ou entregue e recolhido pessoalmente. Nesse caso o total de entrevistados foi de 100 pessoas.

Tendo em mente que o foco dessa pesquisa é analisar os efeitos da popularização da fotografia, procurou-se descobrir qual o seu grau de acessibilidade na sociedade contemporânea. Para isso, buscou-se analisar, por meio do questionário objetivo, quantos entre os entrevistados possuem câmera fotográfica. 


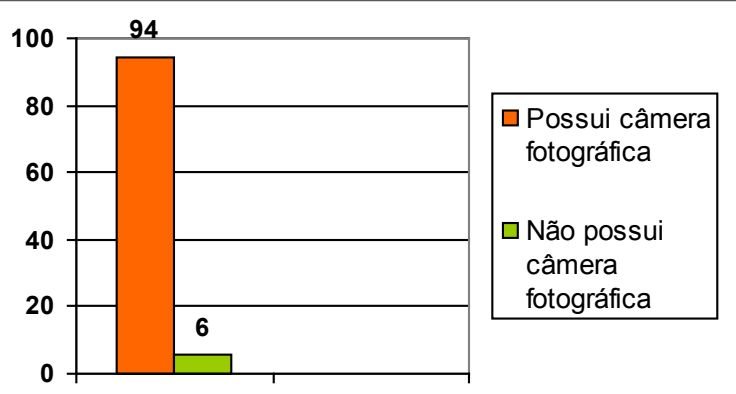

Como se pode observar, $94 \%$ dos entrevistados possue câmera fotográfica, o que sustenta a teoria de que está ocorrendo certa popularização da fotografia. Uma vez analisado tal assunto, procurou-se compreender o quanto a evolução tecnológica contribuiu para que ocorresse tal popularização. Para isso, buscou-se saber quantos dos respondentes possuem câmera digital.

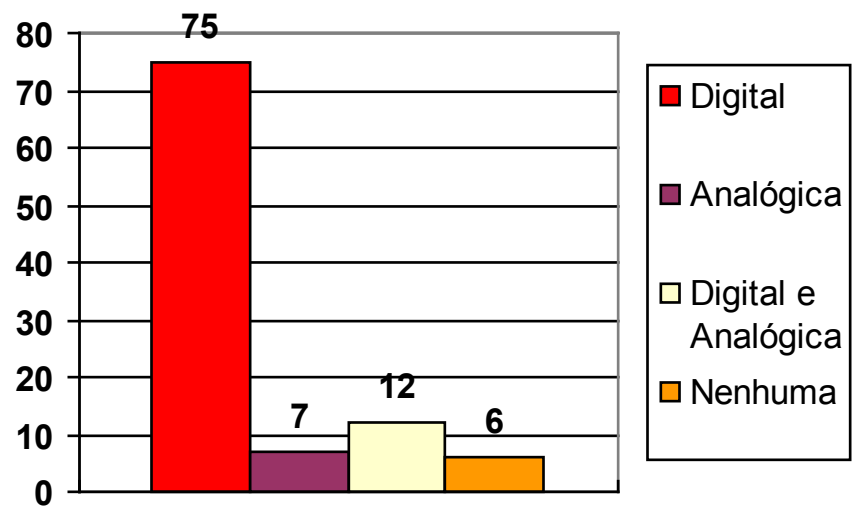

Nota-se que a maior parte dos respondentes (74\%) possui câmeras digitais. Dessa forma, observa-se certa "hegemonia" dos equipamentos digitais em relação aos analógicos, podendo-se, assim, afirmar que o advento do equipamento digital teve grande peso na popularização da fotografia. No entanto, deve-se notar, ainda, que há aqueles que possuem tanto o equipamento analógico quanto o digital, ou até mesmo, apenas o analógico. Sendo assim, pode-se cogitar que, da mesma forma como a pintura não se extinguiu com o advento da fotografia, é possível que a fotografia analógica coexista com os processos digitais.

Depois de observado que grande parte dos entrevistados tem acesso ao aparelho fotográfico, procurou-se compreender a visão dos respondentes quanto ao papel desempenhado pela fotografia na sociedade. As opiniões quanto ao assunto mostraram-se bastante divergentes. 

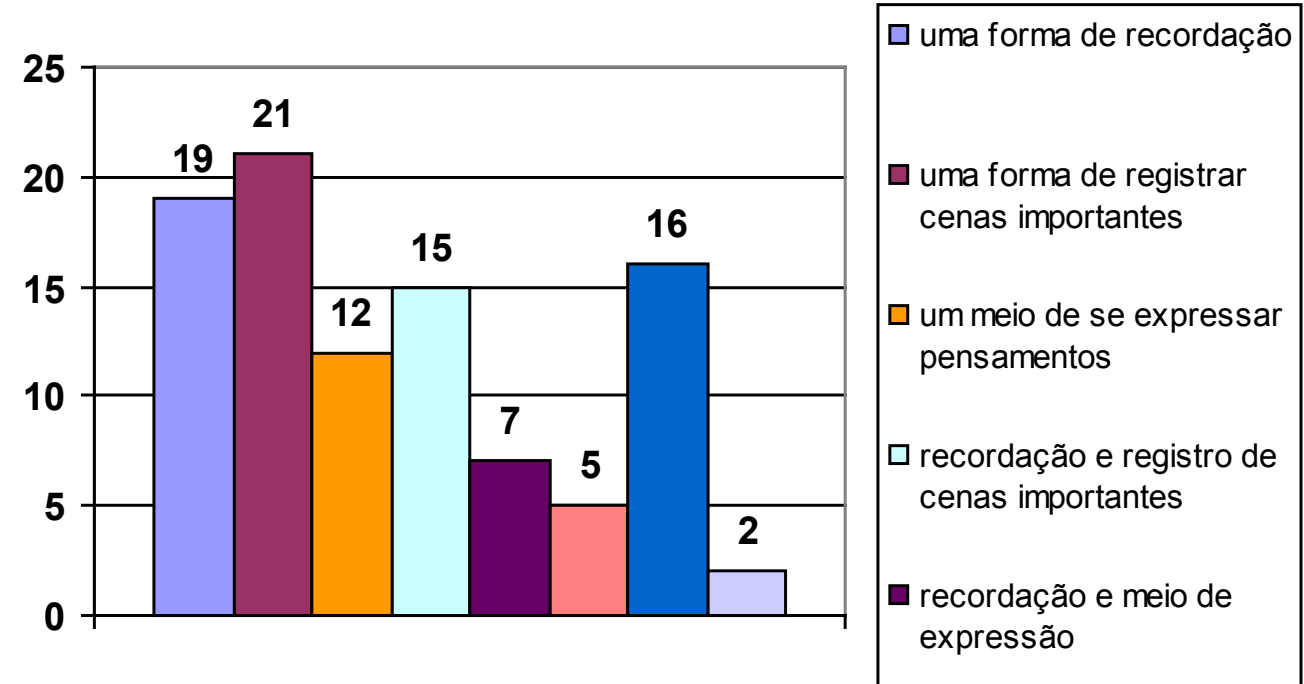

Nota-se que grande parte das respostas voltou-se ao caráter de registro ou recordação/ memória, contrapondo-se a uma minoria que relaciona a fotografia a um meio de expressão de pensamentos. Tal fato traz à luz a questão de que a fotografia é ainda encarada, pela maior parte da sociedade, como depositária da função lhe foi concedida em seus primórdios, ou seja, a de retratação fidedigna do "mundo real".

Também se buscou descobrir qual a opinião dos leigos entrevistados em relação à possibilidade da fotografia tornar-se obsoleta e, consequentemente, de ser substituída por outras mídias.

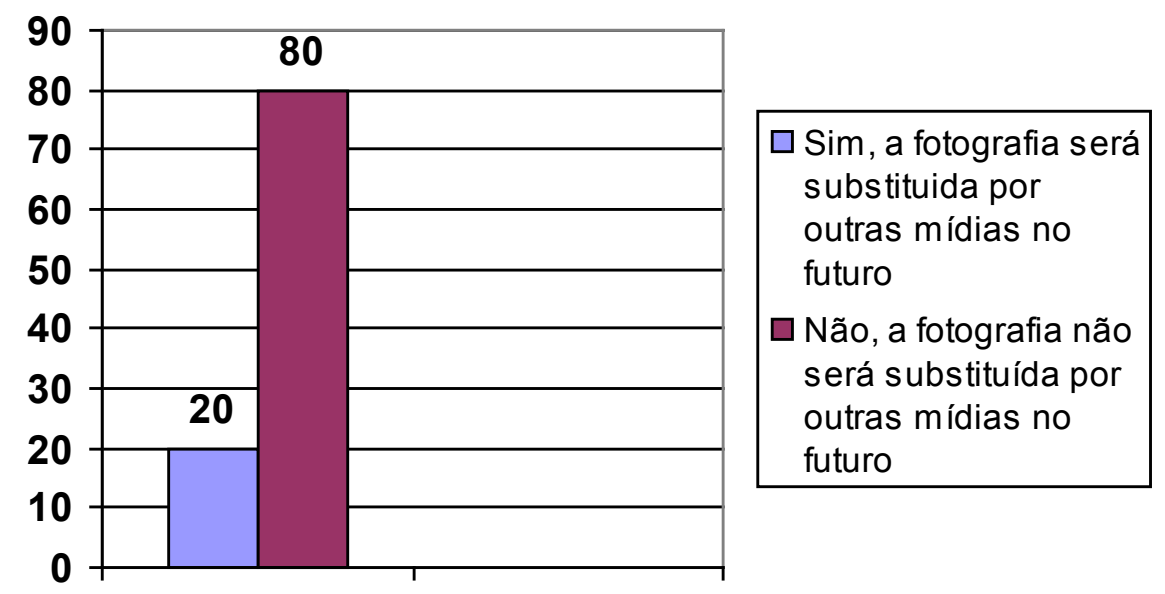

Nesse caso, a maioria, ou seja, $80 \%$ considera que a fotografia não virá a ser substituída por outras mídias, o que contrasta com a opinião de alguns autores citados anteriormente.

Sabendo-se que a sociedade acredita ser a fotografia uma forma de comunicação visual relevante, que não vai ser extinta, buscou-se então compreender a visão que esta tem em relação à função do próprio fotógrafo. 

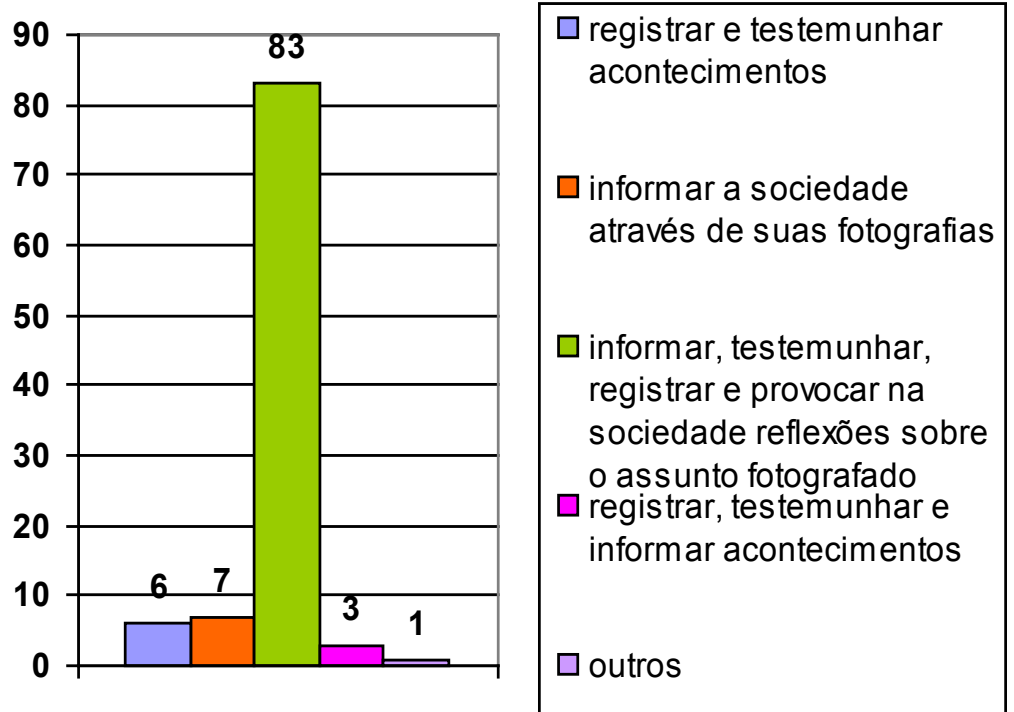

Ao contrário do que se esperava no início da presente pesquisa, grande parte dos leigos entrevistados (83\%) considera o papel do fotógrafo de significativa importância, atribuindo-lhe a tarefa de informar, testemunhar, registrar e provocar, na sociedade, reflexões sobre o assunto fotografado. Essa atribuição confere ao autor das fotografias grande valor perante a sociedade, pois esse deixa de ser apenas alguém responsável por registros, para tornar-se influenciador de opiniões. O fotógrafo não é considerado, assim, apenas como o responsável pelo disparo do botão de uma câmera fotográfica.

Como foi mencionado anteriormente, este estudo buscou não restringir-se apenas à opinião da população leiga quanto ao processo evolutivo da fotografia, mas procurou refletir também sobre a visão dos profissionais da área.

Levando em conta o atual "fácil" acesso aos equipamentos fotográficos na sociedade, primeiramente, questionou-se a opinião dos fotógrafos acerca das diferenças entre os profissionais e os amadores em relação à fotografia. Constatou-se que, para eles, o maior fator de distinção entre o amador e o profissional é a exclusividade em relação à atividade fotográfica.

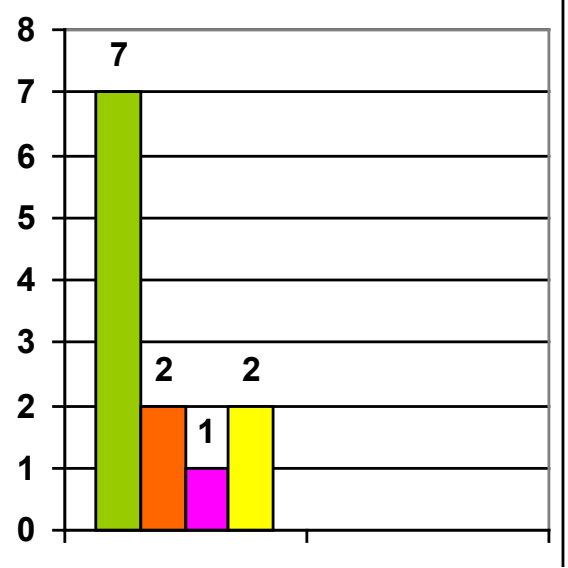

\begin{tabular}{|l|}
\hline O profissional vive da \\
fotografia, enquanto \\
para o amador é apenas \\
um hobby \\
$\square$ A remuneração é a \\
diferença entre o \\
profissional e o amador \\
$\square$ A experiência é o que \\
diferencia o amador do \\
profissional \\
$\square$ outros
\end{tabular}

Sobre esse assunto, o entrevistado número 1 considera que fotógrafo profissional é aquele que sobrevive da atividade fotográfica. 0 entrevistado número 2 compartilha da mesma linha de pensamento, ao afirmar que o profissional vive da fotografia, e o amador fotografa simplesmente por prazer.

Em resposta ao questionário, contrariando o senso comum, o entrevistado número 3 defende que, por vezes, a produção fotográfica do amador pode superar a do profissional, em certos aspectos ao afirmar que a única diferença entre eles é que um vive, profissionalmente, da fotografia e o outro 
A popularização da fotografia e seus efeitos: ... e suas consequências para osfotógrafos e suas produções

não [...] Muitas vezes, por não ter o compromisso de ter que vender a foto, o fotógrafo amador dá mais espaço para a experimentação, para ouvir suas conviç̧ões e pode desenvolver trabalhos mais conscientes, sem as "ditaduras do mercado profissional [...]". O entrevistado número 10 segue um raciocínio diferente do defendido pelos demais entrevistados, ao afirmar que [...] não é a "quantidade de fotos" ou "quantos anos", muito menos o "equipamento" que definem o profissional. [...] Existem alguns detalhes que não se aprende em livros, quanto menos sozinho. É a troca de informações que pode acelerar a evolução da técnica e qualidade [...]

Os equipamentos fotográficos vêm evoluindo espantosamente nas últimas décadas. As câmeras digitais mostram-se cada vez mais compactas e com custos de produção reduzidos. Como conseqüência desse fenômeno, pode-se observar certa popularização da própria fotografia. Tendo isso em mente, objetivou-se considerar também o olhar do profissional quanto a esse fenômeno de popularização, cogitando-se a existência de certa banalização da fotografia. Os entrevistados mostramse divididos, havendo grande controvérsia em relação ao assunto.

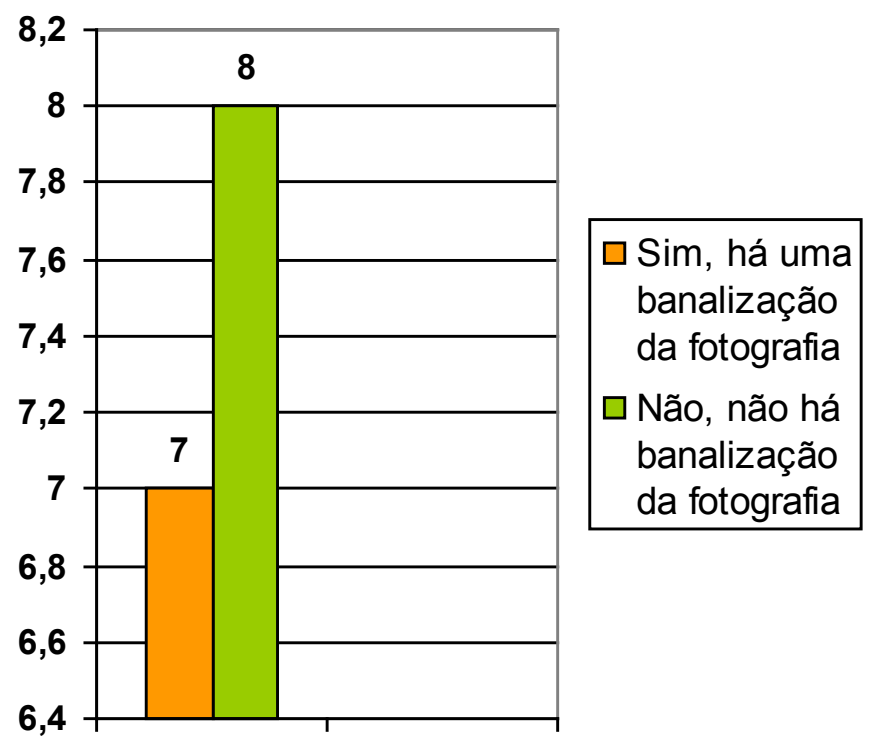

Ao contrário do que se pré-supunha, a forte popularização da fotografia e o seu acelerado nível de produção não são interpretados, pela maior parte dos profissionais entrevistados, como fatores que trouxeram a banalização da fotografia.

O entrevistado número 7 vê o fenômeno da popularização da fotografia como positivo: Quanto mais se popularizar, melhor, hoje se fotografa com câmeras compactas, celulares, webcams. Alimentar a prática da fotografia é criar motivação, cabe aos profissionais criar produtos e serviços para seduzir os anseios dos clientes. [...]. O entrevistado número 8 corrobora ao afirmar: [...] Quanto mais pessoas fotografarem melhor, afinal é um modo de expressão [...]. Em resposta ao questionário, o entrevistado número 6 afirmou que [...] jamais a imagem será banalizada, popularizada sim. 0 entrevistado número 8 também considera a popularização da fotografia como um fenômeno positivo, chegando até a observar que com isso [...] democratiza-se o discurso visual [...].

Já o entrevistado número 9 expressa uma visão diferente: Sim, ocorre uma banalização. O Orkut é um exemplo. Fotos péssimas e fora de foco. Este último é o princípio básico, informado em qualquer manual. [...]. O respondente entrevistado número 4 também acredita que haja certa banalização da imagem fotográfica. Em relação a esse assunto, ele relata que [...] a banalização está aí, hoje mesmo recebi uma resposta de uma agência dizendo que não faríamos mais o trabalho, pois o próprio cliente fez as fotos (que acredita serem boas) e assim desenvolverá as peças da campanha [...]. Ainda sobre a banalização das fotografias, o entrevistado número 5 afirma: Acho sim que a imagem está banalizada. Mas acredito que a saturação vai atingir um teto e vai cansar. Hoje, o que se vê é um excesso de fotografias tratadas e manipuladas ao extremo. É um deslumbramento da tecnologia. Daqui a pouco, 
perde a graça, como brinquedo de criança.

Como questão final a ser analisada, levando-se em conta o contexto atual da "era da internet", buscou-se analisar o posicionamento dos fotógrafos em relação aos inúmeros meios de veiculação da imagem presentes na mídia (fotologs, blogs, sites de banco de imagens etc.) e a facilidade de exposição das fotografias trazidas por esses meios de comunicação. Verificou-se que a maior parte dos entrevistados encara essa facilidade de exposição como uma mudança positiva.

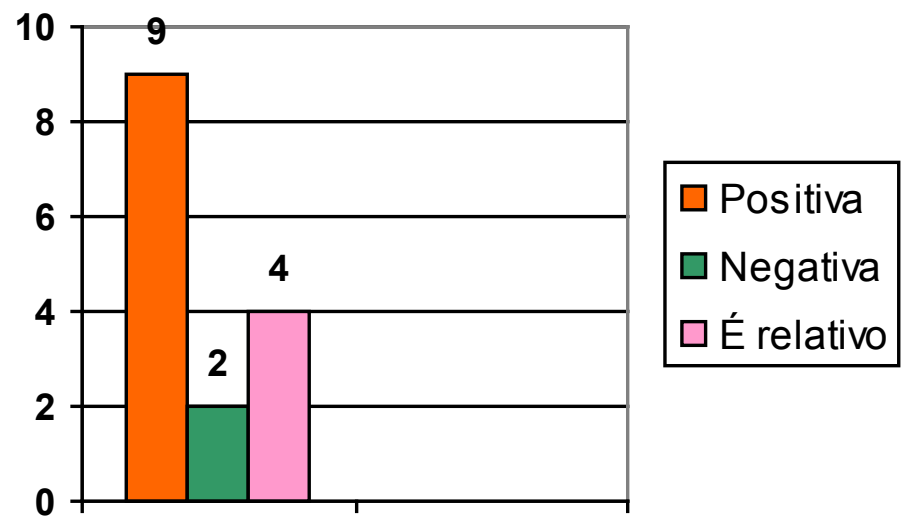

Sobre esse assunto o entrevistado número 3 mostra-se otimista e afirma que: [...] Muita gente expõe, publica e mostra seus pensamentos, possibilitando uma troca de cultura e conhecimentos cada vez maior [...].

O entrevistado número 4 mostra que há tanto efeitos positivos quanto negativos em relação aos novos meios de exposição da fotografia. Para ele, o ponto positivo é visibilidade, estar disponível em todos os lugares, para todos. Porém existe a banalização. Estar em todos os lugares é relativo, pois que lugares são esses? Muitas vezes, é melhor estar em poucos, porém bons endereços. O entrevistado número 2 tece um comentário bastante interessante ao afirmar: Acho que é positiva pelo avanço técnico e pela praticidade em termos de criação e divulgação. Entretanto, fico imaginando como vamos, eventualmente, separar a boa fotografia da "ordinária" com uma produção tão grande e tão descartável, na maioria das vezes.

Por fim, em resposta à indagação em relação aos efeitos positivos ou negativos trazidos pela evolução tecnológica e popularização da imagem, o entrevistado número 6 responde à pergunta por meio de outra indagação: daqui a cinqüenta anos, como será a fotografia?

\section{Considerações Finais}

A evolução dos processos de produção da imagem fotográfica, principalmente após o advento da tecnologia digital, potencializou/catalisou a popularização da fotografia. Tal popularização, inevitavelmente, trouxe mudanças para os fotógrafos profissionais e suas produções, pois, em tempos em que praticamente todos têm acesso ao equipamento fotográfico, e, consequentemente, produzem fotografias, os profissionais tiveram que passar por certas adaptações. Porém, é igualmente importante pontuar que mudanças ocorrem também sobre o modo como a fotografia é vista e tratada pela sociedade.

Do ponto de vista daqueles que têm como ofício a fotografia, os assim "intitulados" fotógrafos profissionais, são divergentes as opiniões acerca dos efeitos trazidos pela popularização da mesma. Existe o pensamento de que a popularização trouxe fatores negativos, como a desvalorização do ofício e até mesmo da própria fotografia. No entanto, há também os que defendem a ideia de que essa popularização resultou numa crescente diversificação e na troca de informações no âmbito fotográfico, chegando até mesmo ser possível falar em democratização dessa linguagem visual. De qualquer forma, o que se observou ser largamente defendido é o fato de que, devido ao alargamento da produção da fotografia, seja por amadores ou profissionais, os fotógrafos devem elevar a qualidade de suas 
A popularização da fotografia e seus efeitos: ... e suas consequências para osfotógrafos e suas produções

produções, não só no aspecto técnico, mas também no estético e conceitual, de modo que possam criar diferenciais e expressarem o real valor de suas imagens.

Por meio da pesquisa de campo realizada, foi possível observar que os leigos também têm conhecimento sobre a importância da fotografia, pois notou-se uma certa evolução sobre o modo como a sociedade a vê.

Acredita-se que a popularização dos aparatos fotográficos iniciou um novo processo que se traduz pela democratização da fotografia. Todos passam a ter a possibilidade e o direito de produzir imagens fotográficas, o que contribui para a diversificação das informações e dos discursos visuais, no entanto, é necessário não perder de vista o senso crítico e o apreço pelo desenvolvimento de produções inovadoras e relevantes, neste cenário de constantes transformações no âmbito da atividade fotográfica.

\section{Referências}

ARNHEIM, Rudolf. Arte e Percepção Visual: uma psicologia da visão criadora. São Paulo: Thomson Pioneira, 1998.

BARTHES, Roland. A câmara clara: nota sobre a fotografia. Trad. Júlio Castanõn Guimarães. 7. ed. Rio de Janeiro: Nova Fronteira, 1984.

BENJAMIN, Walter. Magia e técnica, arte e política. Trad. Sergio Paulo Rouanet. 4. ed. São Paulo: Brasiliense, 1985.

BONI, Paulo César. Discursos Fotográficos. Londrina: Planográfica, 2008.

CAMARGO, Isaac Antonio. Reflexões sobre o pensamento fotográfico: pequena introdução às imagens e a fotografia. Londrina: Eduel, 1999.

org.DOMINGUES, Diana. A arte no século XXI. A humanização das tecnologias. São Paulo: Unesp, 1997.

DONDIS, Donis A. Sintaxe da Linguagem Visual. Trad. Jefferson Luiz Camargo. 3. ed. São Paulo: Martins Fontes, 2007.

DUBOIS, Philippe. O ato fotográfico e outros ensaios. 11. ed. São Paulo: Papirus, 1993.

FABRIS, Annateresa. Discutindo a imagem fotográfica. Disponível em: http://www.

fotografiacontemporanea.com.br/v07/artigo.asp?artigold=3369D5.

Acessado em: 25 mai. 2009.

FERREIRA, Aurélio Buarque de Holanda. Míni Aurélio: o dicionário de língua portuguesa. 7.ed. Curitiba: Positivo, 2008.

FLUSSER, Vilém. Filosofia da caixa preta: Ensaios para uma futura filosofia da fotografia. São Paulo: Hucitec, 1985.

FRÓES, R. M. Jorge. Educação e Informática: A Relação Homem/Máquina e a Questão da Cognição. Disponível em: http://www.edutec.net/Textos/Alia/PROINFO/prf_txtie04.htm. Acessado em: 23 mai. 2009.

KOSSOY, Boris. Fotografia \& história. 2.ed.São Paulo: Ateliê Editorial, 2003.

LOUREIRO, Clovis. A linguagem da fotografia. Disponível em: http://www.fotografiacontemporanea. com.br/v07/artigo.asp?artigold=3334012E. Acessado em: 27 mar. 2009. 
Kawakami ,Tatiana Tissa;Veiga, Adriana Imbriani Marchi

MACHADO, Arlindo. A ilusão especular: introdução à fotografia. São Paulo: Brasiliense, 1984.

MACHADO, Arlindo. Máquina e imaginário: o desafio das poéticas tecnológicas. 3 ed. São Paulo:

Edusp, 2001.

MOREIRO, José Antônio; ARILLO, Jesus Robledano. O contéudo da imagem. Curitiba: Ed. UFPR, 2003.

MORELLI, Rinaldo. Fotografia Abstrata. Disponível em: http://www.fotografiacontemporanea.com. br/v07/artigo.asp?artigold=3339D2. Acessado em: 27 mar. 2009.

PERSICHETTI, Simonetta. Imagens da fotografia brasileira. 2 ed. São Paulo: SENAC São Paulo, 2000.

SAMAIN, Etienne. O fotográfico. 2. ed. São Paulo: Hucitec, 2005.

SANTAELLA, Lúcia; NOTH, Winfried. Imagem - cognição; semiótica; mídia. 4. ed.São Paulo: lluminuras, 1998.

SONTANG, Susan. Sobre fotografia. São Paulo: Companhia das letras, 2007. 